\title{
One-pot intercalation strategy for the encapsulation of a CO- releasing organometallic molecule in a layered double hydroxide
}

\author{
Isabel M. Calhau, ${ }^{[a]}$ Ana C. Gomes, ${ }^{[a]}$ Sofia M. Bruno, ${ }^{[a]}$ Ana C. Coelho, ${ }^{[b]}$ Clara I. R. Magalhães, ${ }^{[a]}$ \\ Carlos C. Romão, ${ }^{[b]}$ Anabela A. Valente, ${ }^{[a]}$ Isabel S. Gonçalves, ${ }^{*[a]}$ and Martyn Pillinger ${ }^{*[a]}$
}

\begin{abstract}
The photoactivatable CO-releasing molecule (photoCORM) $\left[\mathrm{Mo}(\mathrm{CO})_{3}\left(\mathrm{CNCH}_{2} \mathrm{COOH}\right)_{3}\right] \quad(\mathrm{ALF} 795)$ has been incorporated into a $\mathrm{Zn}, \mathrm{Al}$ layered double hydroxide (LDH) host by a coprecipitation synthesis strategy. Powder X-ray diffraction (PXRD) of the resultant material Zn,Al-ALF795 showed that the ALF795 guest molecules assembled into a monolayer to give a basal spacing of $16.0 \AA$. FTIR and ${ }^{13} \mathrm{C}\left\{{ }^{1} \mathrm{H}\right\} \mathrm{CP}$ MAS NMR spectroscopies confirmed that the molecular structure of the tricarbonyl complex was retained upon intercalation. Scanning electron microscopy (SEM), energydispersive X-ray spectroscopy (EDS) and elemental analyses confirmed the phase-purity of Zn,Al-ALF795. The myoglobin assay was used to demonstrate that intercalated ALF795 retains the photoactive behavior of the free CORM, with a substantial fraction $(42 \%)$ of the high CO payload $\left(2.46 \mathrm{mmol} \mathrm{g}^{-1}\right)$ being released after exposure to UV light for $3 \mathrm{~h}$ under simulated physiological conditions. In addition, gas chromatography was used to track sequential lightand $\mathrm{H}_{2} \mathrm{O}_{2}$-triggered decarbonylation of free and intercalated ALF795. In biological buffer solution (HEPES), less than $2 \%$ Mo leaching from $\mathrm{Zn}, \mathrm{Al}$-ALF795 took place after $5 \mathrm{~h}$, showing the strong capacity of the $\mathrm{LDH}$ host to retain the unaltered complex and decarbonylation fragments.
\end{abstract}

\section{Introduction}

Carbon monoxide is a poisonous gas that cannot be seen, smelled or tasted. Prolonged exposure or acute exposure to high concentrations of $\mathrm{CO}$ can cause serious illness, coma and death. ${ }^{[1]}$ For these reasons it has been called "the silent killer" ever since its toxicity was revealed by Claude Bernard in 1857. ${ }^{[2]}$ The toxic effects of $\mathrm{CO}$ arise from its capacity to bind strongly to hemoglobin and so prevent oxygen transport and delivery throughout the body. In the middle of the $20^{\text {th }}$ century the image of $\mathrm{CO}$ as just a noxious gas began to change with the discovery that it is produced endogenously in the human body, mainly from the heme oxygenase-catalyzed degradation of heme..$^{[3]}$ Endogeneous $\mathrm{CO}$ is now recognized as an essential signaling molecule with cell protective, anti-inflammatory, and vasodilatory functions. ${ }^{[4]}$ Often, however, the beneficial effects of the hemeoxygenase defense system and endogenous $\mathrm{CO}$ are not strong

[a] Ms. I. M. Calhau, Dr. A. C. Gomes, Dr. S. M. Bruno, Ms. C. I. R Magalhães, Dr. A. A. Valente, Prof. Dr. I. S. Gonçalves, Dr. M. Pillinger

CICECO - Aveiro Institute of Materials, Department of Chemistry, University of Aveiro, Campus Universitário de Santiago, 3810-193 Aveiro, Portugal

E-mail: igoncalves@ua.pt (I.S.G.)

Homepage: http://www.ciceco.ua.pt//sabe/Goncalves E-mail: mpillinger@ua.pt (M.P.)

Homepage: http://www.ciceco.ua.pt/MartynPillinger

[b] Dr. A. C. Coelho, Prof. C. C. Romão

Instituto de Tecnologia Química e Biológica António Xavier,

Universidade Nova de Lisboa, Av. da República, EAN, 2780-157, Oeiras, Portugal enough to ensure efficient cytoprotection. Fortunately, these innate immune defenses may be enhanced by administration of exogenous $\mathrm{CO}$ and this has been explored in multiple clinical trials that use gas inhalation as the delivery method. ${ }^{[5]} \mathrm{CO}$ has tremendous therapeutic potential in ailments such as rheumatoid arthritis, gastric ulcers, sepsis, lung injury, cardiovascular disease, stroke, transplant rejection, and cancer. ${ }^{[6-8]}$

Major drawbacks of $\mathrm{CO}$ delivery by inhalation as a gas include lack of tissue specificity, requirement to be performed in a hospital setting, and high dependence of the outcome on the respiratory function of the patient. ${ }^{[5]}$ Solid or liquid dosage of $\mathrm{CO}$ has been investigated since 2002 by the development of COreleasing molecules (CORMs). ${ }^{[6-10]}$ Most CORMs developed to date are organometallic carbonyl complexes with $\mathrm{CO}$ bound to a transition metal in a low oxidation state, e.g. $\left[\mathrm{Ru}(\mathrm{CO})_{3} \mathrm{Cl}\right.$ (glycinate)] (CORM-3). ${ }^{[11]}$ Multiple studies with such compounds have confirmed the beneficial effects of $\mathrm{CO}$ in different animal models of diseases. ${ }^{[7-9]} \mathrm{CO}$ release from CORMs may be triggered hydrolytically, by ligand substitution, photoactivation (so-called photoCORMs), changes in $\mathrm{pH}$, exposure to reactive oxygen species (ROS), and enzymatic hydrolysis. ${ }^{[8,12-14]}$ However, in many instances the direct delivery of molecular CORMs is likely to be inefficient and may suffer from problems such as enzymatic degradation, poor bioavailability, poor circulation stability, and liberation of $\mathrm{CO}$ prior to reaching the target tissues. A rapid release of $\mathrm{CO}$ could lead to concentrations high enough to cause toxicity and side-effects. Hence, for certain applications, a slow release of $\mathrm{CO}$ in the blood or in specific target tissues may be desirable. The hybridization of CORMs with physiologically compatible macromolecular or inorganic scaffolds is a promising approach towards achieving a sustainable and controlled release of $\mathrm{CO}$, with two key benefits being the prevention of the premature interaction of the CORM with the biological environment, and the retention of potentially toxic decarbonylation fragments. ${ }^{[15-19]} \mathrm{CO}-$ releasing materials (CORMAs) have been prepared by immobilizing CORMs in a micellar system, ${ }^{[20]}$ functionalized nanodiamond, ${ }^{[21]}$ silica, iron oxide and mesoporous AI-MCM-41 nanoparticles, ${ }^{[22-25]}$ graphene oxide nanosheets, ${ }^{[26]}$ nonwovens, ${ }^{[27]}$ and metal-organic frameworks. ${ }^{[28-33]}$

Layered double hydroxides (LDHs) are well established as biocompatible nanocarriers of anionic drugs and biomolecules. ${ }^{[34-37]}$ The structure of LDHs consists of the periodical stacking of positively charged metal hydroxide layers, typically containing divalent and trivalent metal cations, and negatively charged interlayers consisting of anions and water molecules. ${ }^{[38,39]}$ LDHs possess valuable characteristics for use in biomedicine, such as low cytotoxicity, good biocompatibility and biodegradability, high drug loading, protection of drugs in the interlayer, and control of particle size. Mammalian cells internalize positively charged LDH nanoparticles very quickly via clathrin-mediated endocytosis. ${ }^{[37,40,41]}$ The suitability of LDHs as hosts for molybdenum carbonyl complexes was demonstrated in 
three recent studies in which materials intercalated by the $\pi$-allyl complex $\left[\mathrm{Mo}\left(\eta^{3} \text {-allyl }\right) \mathrm{Cl}(\mathrm{CO})_{2}(\mathrm{bpdc})\right]^{2-}\left(\mathrm{bpdc}=2,2^{\prime}\right.$-bipyridine$5,5^{\prime}$-dicarboxylate), the tetracarbonyl complex cis$\left[\mathrm{Mo}(\mathrm{CO})_{4}(\mathrm{bpdc})\right]$ and the cyclopentadienyl complex $\left[\mathrm{CpMo}(\mathrm{CO})_{3}\left(\mathrm{CH}_{2} \mathrm{COO}\right)\right]^{-}$were prepared. ${ }^{[42-44]}$ Exposure of the intercalated tetracarbonyl complex to visible light promoted decarbonylation, pointing to a possible application as a photoactivatable CORMA. However, the CO release behavior of these materials or, for that matter, other LDH/CORM hybrids, has not yet been studied from the CORMA perspective.

Molybdenum tricarbonyl complexes with isocyanoacetate ligands of general formula $\left[\mathrm{Mo}(\mathrm{CO})_{3}\left(\mathrm{CNCR}^{\prime} \mathrm{R}^{\prime \prime} \mathrm{COOR}^{\prime \prime \prime}\right)_{3}\right]$ are a promising family of CORMs. ${ }^{[45]}$ These complexes are nontoxic, air stable and soluble in aqueous solutions at the physiological $\mathrm{pH}$ of 7.4 , and $\mathrm{CO}$ release can be bioactivated and/or light activated. Another advantage is that the complexes are tunable (by variation of the substituents $\mathrm{R}$ ) to achieve tissue specificity. Nevertheless, for the reasons outlined above, several performance gains may be achieved by combining the CORMs with biocompatible solids. Carmona et al. loaded the complex $\left[\mathrm{Mo}(\mathrm{CO})_{3}\left(\mathrm{CNCMe}_{2} \mathrm{COOH}\right)_{3}\right](\mathrm{ALF} 794)$ in zinc- and aluminiumbased metal-organic frameworks (MOFs) by either one-pot synthesis-encapsulation or solid-liquid impregnation strategies. ${ }^{[31,32]}$ They found that the hybrid materials retained the photoactive properties of the pristine CORM, protected the drug towards premature degradation, and retained most of the potentially toxic decarbonylation fragments. In the present work, a novel CORMA with a high $\mathrm{CO}$ payload has been prepared by a one-pot synthesis-intercalation strategy using a $\mathrm{Zn}, \mathrm{Al} \mathrm{LDH}$ as host and the photoCORM $\left[\mathrm{Mo}(\mathrm{CO})_{3}\left(\mathrm{CNCH}_{2} \mathrm{COOH}\right)_{3}\right]$ (ALF795). The structural characteristics and $\mathrm{CO}$ releasing properties of the hybrid material are described.

\section{Results and Discussion}

\section{Synthesis and characterization}

The synthetic methodology adopted in the present work was founded on previous experience gained with efforts to intercalate other molybdenum carbonyl complexes in LDHs. Of the various methods available, the direct coprecipitation method is often the most suitable, and was used to incorporate the allyl dicarbonyl complex $\left[\mathrm{Mo}\left(\eta^{3} \text {-allyl) } \mathrm{Cl}(\mathrm{CO})_{2}(\mathrm{bpdc})\right]^{2-}\right.$ and the half-sandwich complex $\left[\mathrm{CpMo}(\mathrm{CO})_{3}\left(\mathrm{CH}_{2} \mathrm{COO}\right)\right]^{-}$in $\mathrm{Zn}, \mathrm{Al}$ LDHs. ${ }^{[42,44]}$ This approach was used successfully in the present work to intercalate the tricarbonyl complex $\left[\mathrm{Mo}(\mathrm{CO})_{3}\left(\mathrm{CNCH}_{2} \mathrm{COO}\right)_{3}\right]^{3-}$ (ALF795), giving the material abbreviated as Zn,Al-ALF795.

The PXRD pattern of Zn,Al-ALF795 is shown in Figure 1. Five symmetric and equally spaced peaks between 5 and $30^{\circ} 2 \theta$ are assigned as the $(00 /)$ reflections of an expanded hydrotalcite-type LDH phase with a basal spacing $\left(d_{(003)}\right)$ of 16.0 A. A model for the molecular structure of ALF795 was generated by using the crystal structure previously reported for the complex $\left[\mathrm{Mo}(\mathrm{CO})_{3}\left(\mathrm{CNCMe}_{2} \mathrm{COOMe}\right)_{3}\right]$ (ALF793). ${ }^{[45]}$ The methyl groups in the unit $\mathrm{CMe}_{2}$ were replaced by hydrogen atoms $(\mathrm{C}-\mathrm{H}=0.96 \AA)$, the methyl group of the ester functionality was removed, and the $\mathrm{C}-\mathrm{O}$ bond lengths of the carboxylate groups were adjusted to the typical uniform value of $1.27 \AA$, with a $\angle \mathrm{OCO}$ angle of $120^{\circ}$.
A plausible interlayer arrangement of the tricarbonyl complexes was arrived at by considering that the guest molecule orientation should be such that the following criteria are met: (i) maximize hydrogen-bonding interactions between the carboxylate oxygen atoms and the layer hydroxyl groups, while positioning the $\mathrm{CO}$ groups towards the center of the interlayer region; (ii) be consistent with a gallery height of $11.2 \AA$ (taking into account van der Waals (vdW) radii for the carboxylate oxygen atoms), which is the experimental value obtained upon subtraction of the LDH layer thickness of $4.8 \AA$ from the observed basal spacing; (iii) allow the anionic guest to be spatially capable of compensating the host layer positive charge. Figure 2 shows an interlayer arrangement that meets these requirements. In this orientation, the cross-sectional area occupied by the guest molecules in a plane parallel with the layers is estimated as 72 $\AA^{2}$, which corresponds to an area per unit charge of $24 \AA^{2}$. An $\mathrm{LDH}$ with the general formula $\left[\mathrm{Zn}_{0.67} \mathrm{Al}_{0.33}(\mathrm{OH})_{2}\right]^{0.33^{+}}$is predicted to have an area per unit positive charge of $25.0 \AA^{2}$ (given by $(1 / x) a_{0}{ }^{2} \sin 60^{\circ}$, where $x=0.33$ for an LDH with $\mathrm{Zn} / \mathrm{Al}=2$, and a value of $3.1 \AA$ is taken for the hexagonal unit cell parameter $a_{\circ}$ ). It follows that a monolayer of closely packed tricarbonyl complexes, as schematically represented in Figure 2, could be capable of fully compensating the host layer charge. In Figure 2 the guest molecules are positioned such that the distance between adjacent Mo atoms is about $9.3 \AA$, which corresponds to the calculated spacing for a hypothetical hexagonal arrangement in which the effective area occupied by each molecule is $75 \AA^{2}$.

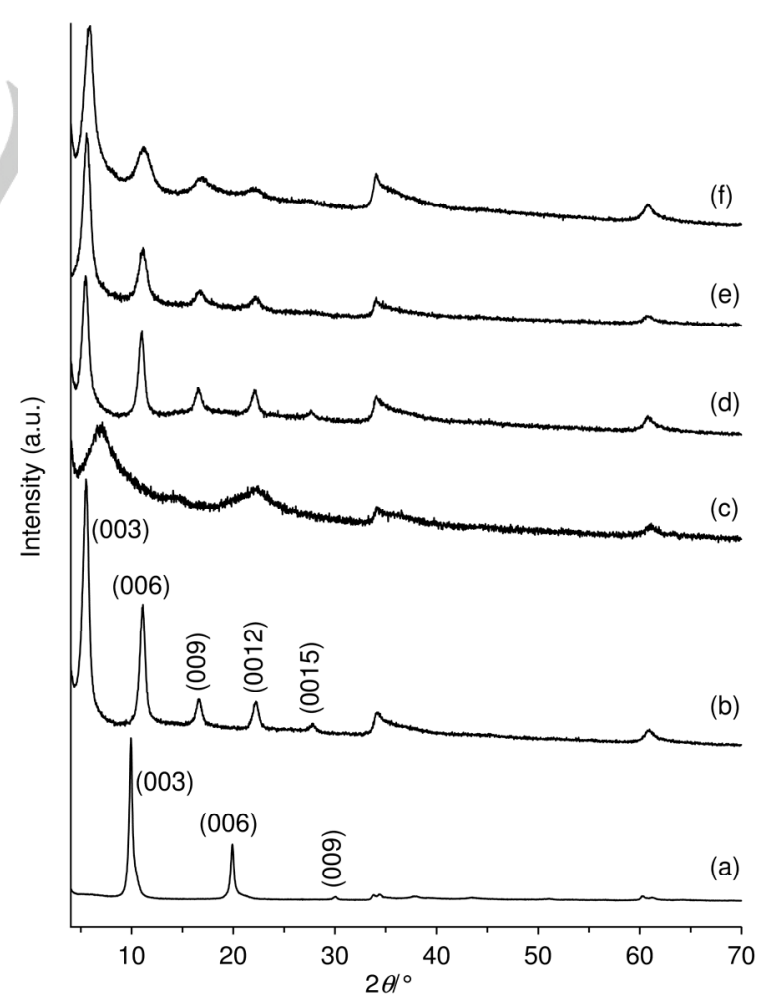

Figure 1. PXRD patterns of (a) Zn, Al-NO ALF795P, (d) Zn,Al-ALF795H, (e) Zn,Al-ALF795L, and (f) Zn,Al-ALF795GC. 


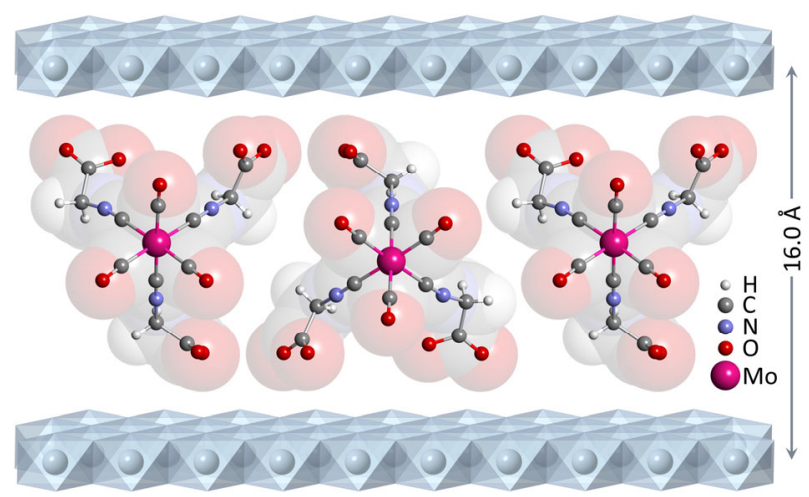

Figure 2. Structural model (ball-and-stick diagram superimposed on a spacefilling, van der Waals-based representation) for the monolayer arrangement of $\left[\mathrm{Mo}(\mathrm{CO})_{3}\left(\mathrm{CNCH}_{2} \mathrm{COO}\right)_{3}\right]^{3-}$ anions in the material $\mathrm{Zn}, \mathrm{Al}-\mathrm{ALF} 795$.

The presence of structurally intact tricarbonyl complexes, $\left[\mathrm{Mo}(\mathrm{CO})_{3}\left(\mathrm{CNCH}_{2} \mathrm{COO}\right)_{3}\right]^{3-}$, in the material $\mathrm{Zn}, \mathrm{Al}-\mathrm{ALF} 795$ was confirm by FTIR (Figure 3 ) and ${ }^{13} \mathrm{C}\left\{{ }^{1} \mathrm{H}\right\}$ CP MAS NMR (Figure 4) spectroscopies. The IR spectrum of the intercalated LDH displays a strong band at $2148 \mathrm{~cm}^{-1}$ and a slightly weaker one at $2181 \mathrm{~cm}^{-1}$ due to $v(\mathrm{CN})$ vibrational modes of the isocyanide group, and two strong $v(\mathrm{CO})$ bands at 1854 (E mode) and 1936 $\mathrm{cm}^{-1}\left(\mathrm{~A}_{1}\right.$ mode), as expected for facial tricarbonyl complexes with approximate $C_{3 \mathrm{v}}$ symmetry. ${ }^{[45,46]}$ The corresponding bands for free ALF795 are found at 1850, 1925, 2158 and $2188 \mathrm{~cm}^{-1}$. Due to lower site symmetry in the crystal, the degeneracy of the E mode is lifted for the free CORM, as evidenced by a splitting of the IR band and the presence of a shoulder on the highfrequency side of the peak centered at $1850 \mathrm{~cm}^{-1}$. The solidstate environment of the $\mathrm{LDH}$-intercalated complex results in a broadening of the $\mathrm{E}$ mode band, while no clear shoulder is observed. Confinement effects, such as the host-guest electrostatic interaction, may be the cause of the small higherenergy shifts observed in the $v(\mathrm{CO})$ bands on going from the free CORM to the intercalated complex. Comparable shifts were observed previously for ALF794 immobilized in MOFs, ${ }^{[31,32]}$ and a manganese tricarbonyl complex incorporated in mesoporous Al-MCM-41 nanoparticles. ${ }^{[24]}$ An important difference between the spectra for the free and intercalated CORM is the absence in the latter of a $v(\mathrm{CO})$ band for the carboxylic acid group, which is present at $1717 \mathrm{~cm}^{-1}$ for free ALF795. Deprotonation of these groups for the intercalated complex is confirmed by the appearance of strong bands at $1386\left(v_{s}\left(C O O O^{-}\right)\right)$and $1612 \mathrm{~cm}^{-1}$ $\left(v_{\text {as }}\left(\mathrm{COO}^{-}\right)\right)$.

The alternative assignment of the band at $1386 \mathrm{~cm}^{-1}$ to an asymmetric $v_{3}$ stretching mode of nitrate ions (present via cointercalation with ALF795 and/or formation of a secondary $\mathrm{Zn}, \mathrm{Al}-$ $\mathrm{NO}_{3}$ phase), which typically appears in the range of $1380-1390$ $\mathrm{cm}^{-1}$, can be excluded since the Raman spectrum of $\mathrm{Zn}, \mathrm{Al}-$ ALF795 contains no band at $\mathrm{ca} .1040 \mathrm{~cm}^{-1}$, while the material $\mathrm{Zn}, \mathrm{Al}-\mathrm{NO}_{3}$ displays a very strong band at this frequency due to a $v_{1}\left(\mathrm{NO}_{3}{ }^{-}\right)$mode (Figure $\mathrm{S} 1$ in the Supporting Information). By the same line of reasoning, Zn,Al-ALF795 has no appreciable carbonate contamination since no band characteristic of carbonate ions $\left(v_{3}\left(\mathrm{CO}_{3}{ }^{2-}\right)\right.$ at ca. $\left.1360 \mathrm{~cm}^{-1}\right)$ is present in the IR spectrum (Figure 3 ).

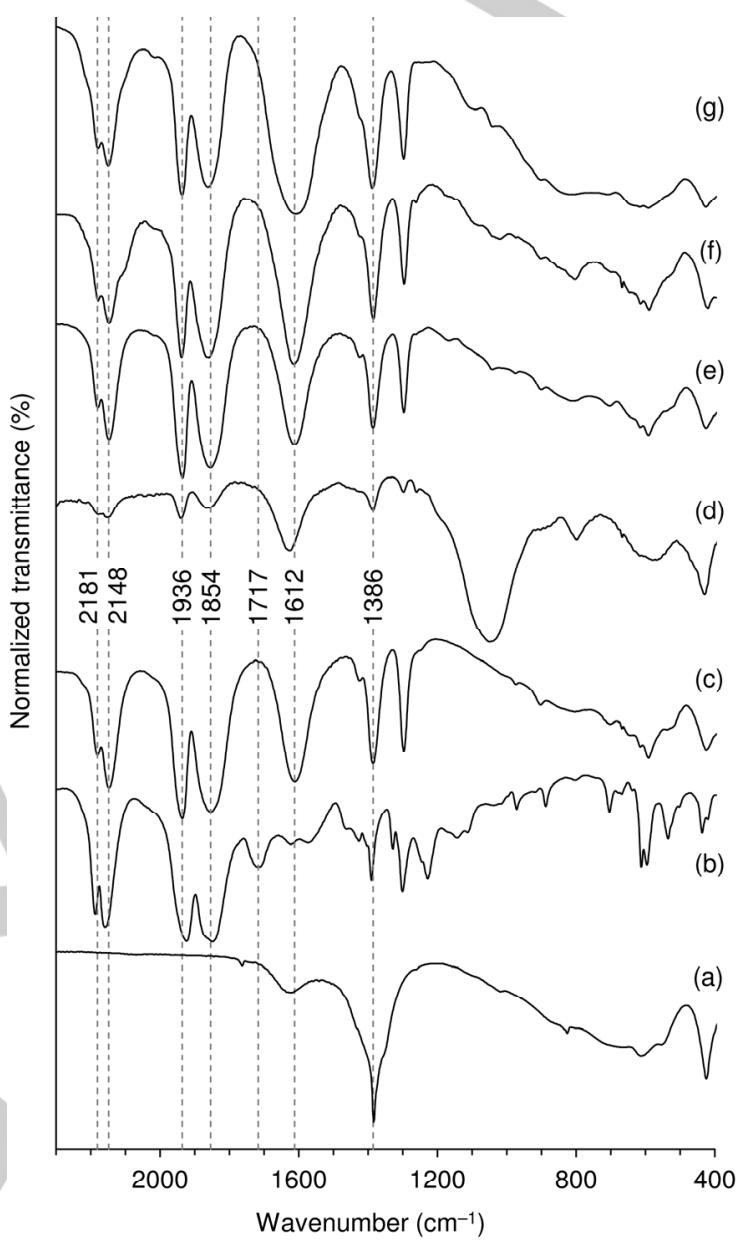

Figure 3. FTIR spectra ( $\mathrm{KBr}$ ) in the range $400-2300 \mathrm{~cm}^{-1}$ of (a) $\mathrm{Zn}, \mathrm{Al}-\mathrm{NO}_{3}$, (b) ALF795, (c) Zn,Al-ALF795, (d) Zn,Al-ALF795P, (e) Zn,Al-ALF795H, (f) Zn,AlALF795L, and (g) Zn,Al-ALF795GC. The guidelines and corresponding frequencies refer to the absorption band maxima observed for ALF795 (1717 $\mathrm{cm}^{-1}$ ) and $\mathrm{Zn}, \mathrm{Al}-\mathrm{ALF} 795$ (all other frequencies).

The ${ }^{13} \mathrm{C}\left\{{ }^{1} \mathrm{H}\right\}$ CP MAS NMR spectrum of the free CORM ALF795 displays a single somewhat broad line for the carboxylic acid group at $158.9 \mathrm{ppm}$ (Figure 4). In contrast, between two and three sharp lines are resolved for each chemically distinct carbon atom from the $\mathrm{CO}, \mathrm{CN}$ and $\mathrm{CH}_{2}$ groups. This suggests that in the solid-state the three carbon atoms for each of these groups are crystallographically inequivalent and therefore resonate at different chemical shifts. The spectrum of the material Zn,Al-ALF795 displays only single somewhat broad lines for the $\mathrm{CO}, \mathrm{CN}, \mathrm{CH}_{2}$ and $\mathrm{COO}^{-}$groups, suggesting that the crystallographic inequivalencies observed for the free CORM are lifted upon incorporation of the complex into the $\mathrm{Zn}, \mathrm{Al}-\mathrm{LDH}$ interlayer.

The phase purity of the material Zn,Al-ALF795 was further checked by SEM and elemental mapping by EDS (Figure 5). The morphology of the intercalated LDH consisted of aggregates 


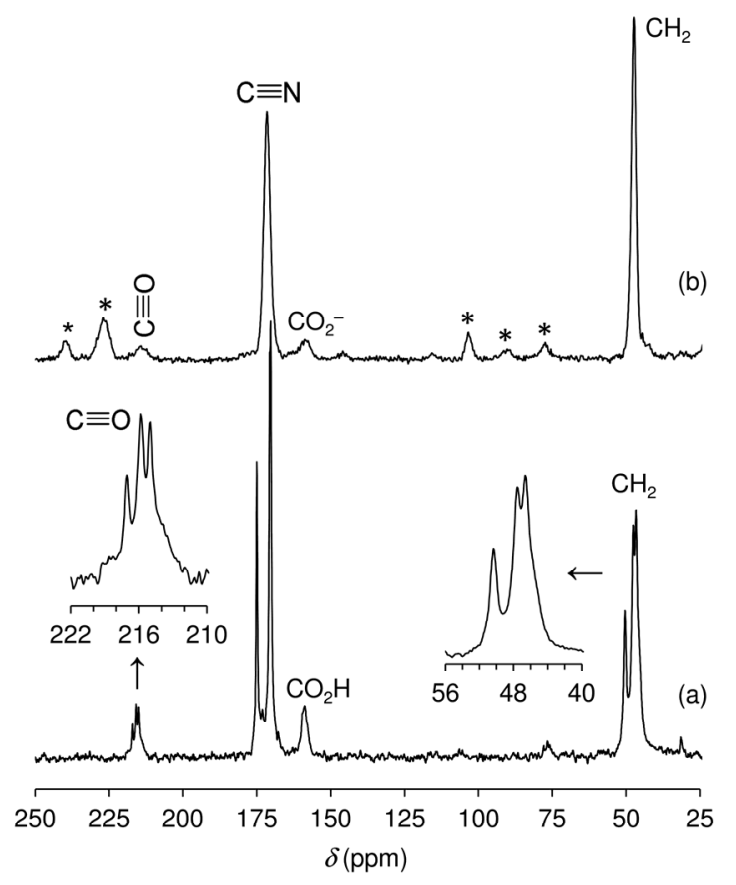

Figure 4. ${ }^{13} \mathrm{C}\left\{{ }^{1} \mathrm{H}\right\}$ CP MAS NMR spectra of (a) ALF795 and (b) Zn,Al-ALF795. Asterisks denote spinning sidebands.
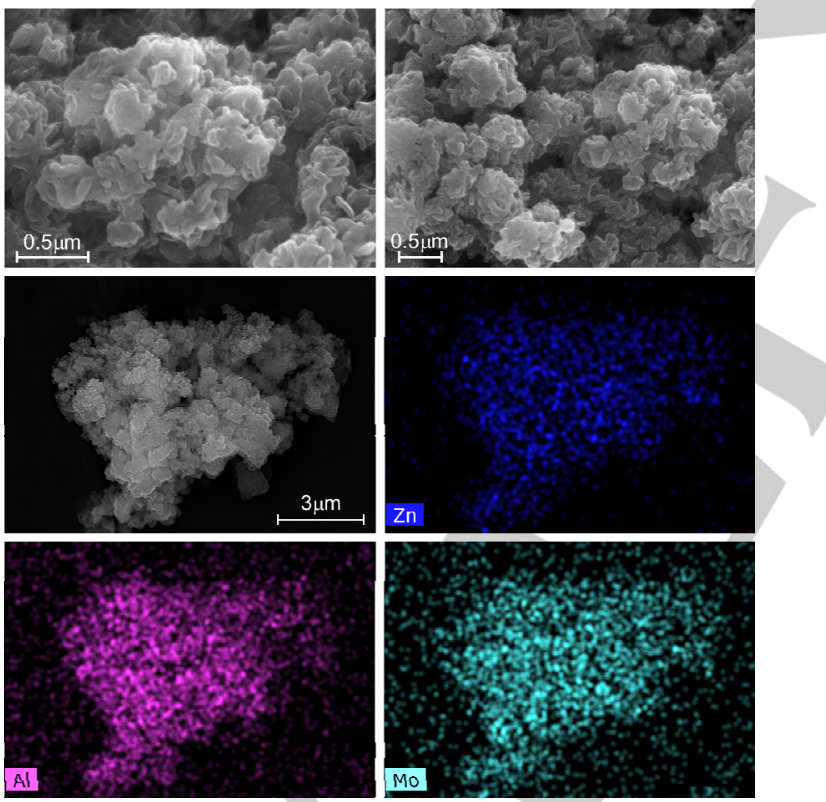

Figure 5. Representative SEM images at different magnifications (10000x, $30000 \times$ and 50000x). EDS elemental mapping images are shown for the sample imaged at the lowest magnification.

of irregular sheet-like or elongated particles with sizes in the range 100-500 $\mathrm{nm}$. Spatial elemental profiles showed a homogeneous distribution of $\mathrm{Zn}, \mathrm{Al}$ and Mo across the particles. No evidence was found for secondary phases containing Zn (e.g $\mathrm{ZnO}$ ) and/or $\mathrm{Al}$ (e.g. $\mathrm{Al}_{2} \mathrm{O}_{3}$ ), in agreement with the PXRD data.
EDS analyses gave an average $\mathrm{Zn} / \mathrm{Al}$ molar ratio of $2.0 \pm 0.1$ and an average $\mathrm{Al} / \mathrm{Mo}$ ratio of $3.0 \pm 0.1$. On the basis of the EDS results and microanalyses for $\mathrm{C}, \mathrm{H}$ and $\mathrm{N}$, the formula $\mathrm{Zn}_{4} \mathrm{Al}_{2}(\mathrm{OH})_{12}\left(\mathrm{Mo}(\mathrm{CO})_{3}\left(\mathrm{CNCH}_{2} \mathrm{COO}\right)_{3}\right)_{0.667} \cdot 3.5 \mathrm{H}_{2} \mathrm{O}$ is assigned to the material Zn,Al-ALF795. Regarding the loading of ALF795, the amount of intercalated CORM is $0.82 \mathrm{mmol} \mathrm{g}^{-1}$ (on a dry basis), which translates to a total CO payload of $2.46 \mathrm{mmol} \mathrm{g}^{-1}$. This value constitutes a high degree of drug loading by the standards of several other CORMAs obtained by the immobilization of tricarbonyl complexes $\left[\mathrm{M}(\mathrm{CO})_{3}(\mathrm{~L})_{n}\right]^{y^{+}}(\mathrm{M}=\mathrm{Mn}$, Mo) in inorganic or metal-organic supports. ${ }^{[21,22,24,25,29,31,32]}$

\section{$\mathrm{CO}$ release studies using the $\mathrm{Mb}$ assay}

The suitability of Zn,Al-ALF795 for the photoinduced delivery of $\mathrm{CO}$ was investigated under simulated physiological conditions $\left(37^{\circ} \mathrm{C}, \mathrm{pH} 7.4\right)$ and compared with the free photoCORM. CO release was quantified by two different analytical procedures, namely the myoglobin (Mb) assay using UV-Vis spectroscopy, and online gas chromatography (GC).

Firstly, the stability of Zn,Al-ALF795 in $10 \mathrm{mM}$ phosphatebuffered saline (PBS) and HEPES (4-(2hydroxyethyl)piperazine-1-ethanesulfonic acid) solutions was studied. For this purpose, the material was incubated in each buffer solution for 3 hours at $37{ }^{\circ} \mathrm{C}$ under an inert nitrogen atmosphere. The IR spectrum of the solid recovered from PBS, denoted $\mathrm{Zn}, \mathrm{Al}-\mathrm{ALF} 795 \mathrm{P}$, showed the appearance of a very strong broad band at $1050 \mathrm{~cm}^{-1}$, assigned to (di)hydrogenophosphate $\left(\mathrm{H}_{m} \mathrm{PO}_{4}{ }^{m-3}, m=1,2\right)$ ions, ${ }^{[47]}$ and a marked decrease in the relative intensity of the $v(\mathrm{CN})$ and $v(\mathrm{CO})$ bands for the complex ALF795 (Figure 3). Hence, deintercalation of the complex occurred by ion-exchange with phosphate ions in the buffer solution, which resulted in the solution turning yellow during the incubation period. The incorporation of phosphate ions in the LDH was confirmed by the PXRD pattern (Figure 1) which shows the formation of a poorly crystalline LDH phase with a lower basal spacing of about $12 \AA$, in agreement with that reported previously for the ionexchange of $\mathrm{H}_{2} \mathrm{PO}_{4}^{-}$ions into a $\mathrm{Zn}, \mathrm{Al}-\mathrm{LDH} \cdot{ }^{[47]}$ In contrast to these results with $\mathrm{PBS}$, no significant alterations in the $I R$ spectrum or PXRD pattern of Zn,Al-ALF795 were observed after its incubation in HEPES (Figures 1 and 3 , material denoted $\mathrm{Zn}, \mathrm{Al}-\mathrm{ALF} 795 \mathrm{H})$. Hence, CO release studies were performed using HEPES, which is one of the favored organic buffers to use for cell cultures and for analysis of biological systems.

The Mb assay is based on the spectrophotometric change of deoxy-myoglobin (deoxy-Mb) to carbonmonoxy-myoglobin (Mb-CO). ${ }^{[48]}$ When kept in the dark, ALF795 does not show spectral changes in the Q-band region (500-600 nm) of $\mathrm{Mb}$ (Figure 6). In contrast, upon irradiation with UV light $(\lambda=365 \mathrm{~nm}$, $8 \mathrm{~mW} \mathrm{~cm}^{-2}$ ), the conversion of deoxy-Mb with $\lambda_{\max }=557 \mathrm{~nm}$ into $\mathrm{Mb}-\mathrm{CO}$ with $\lambda_{\max }=540$ and $577 \mathrm{~nm}$ occurred, indicating $\mathrm{CO}$ release from the metal complex. Approximately 1.5 equiv. of $\mathrm{CO}$ were released per molecule of ALF795 after an irradiation time of $165 \mathrm{~min}$. Results were identical, to within experimental error, for assays performed using stock solutions of ALF795 prepared in either DMSO or HEPES. The half-life of CO release $\left(t_{1 / 2}\right)$, 

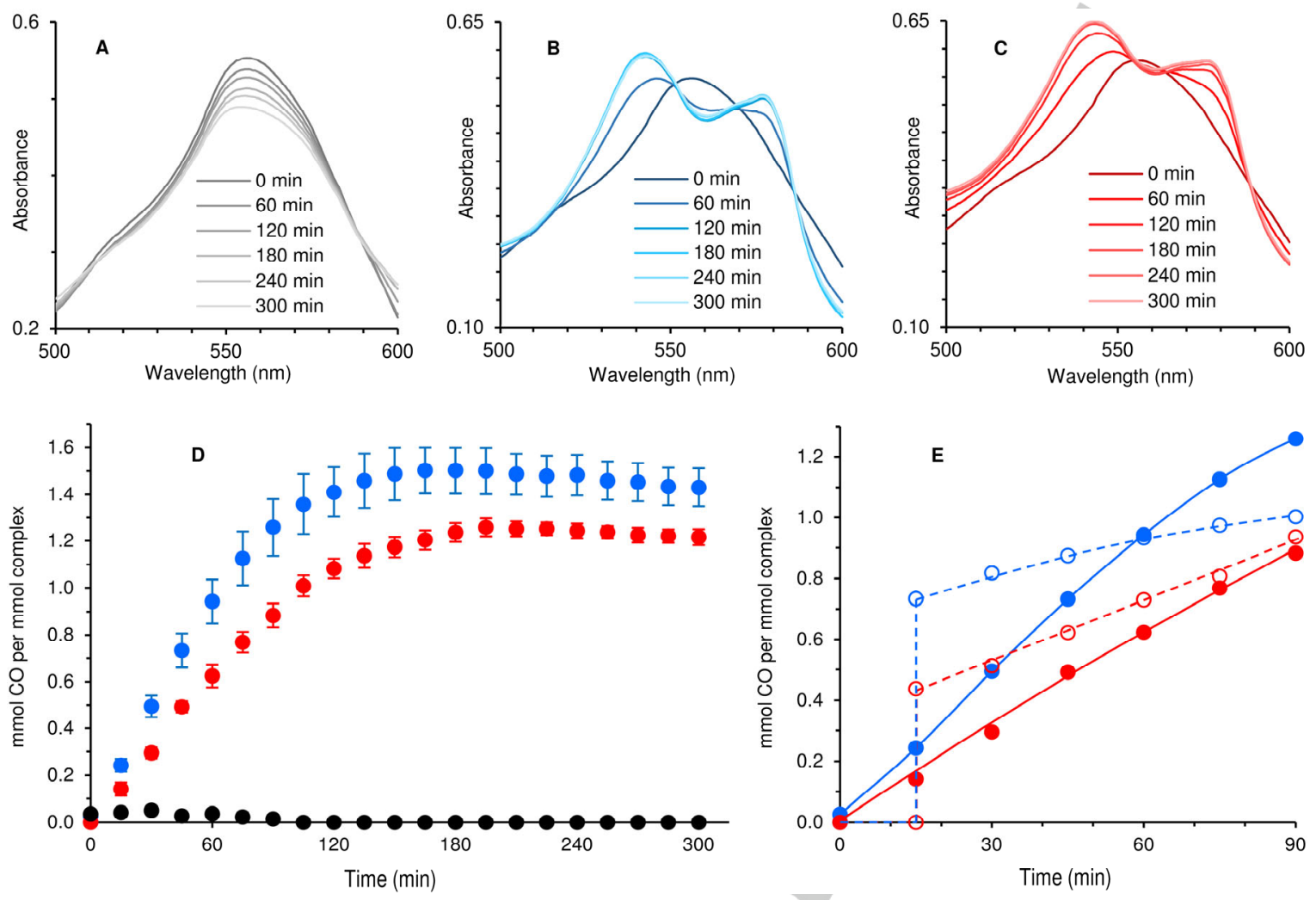

Figure 6. Mb assays of ALF795 (blue points and lines) and Zn,Al-ALF795 (red points and lines) under UV irradiation, and ALF795 in the dark (black/grey points and lines). (A-C) Absorption spectra for (A) ALF795 in the dark, (B) ALF795 under UV irradiation, and (C) Zn,Al-ALF795 under UV irradiation. (D,E) Time courses of $\mathrm{CO}$ release. The filled circles are the normal assays in which the CORM(A), Mb and dithionite were added simultaneously at the start of the assay. Open circles show the results for the addition of $\mathrm{Mb}$ and dithionite $15 \mathrm{~min}$ after ALF795 or Zn,Al-ALF795.

defined as the time taken for a solution of ALF795 with a concentration of $20 \mu \mathrm{M}$ to produce a solution of $\mathrm{Mb}-\mathrm{CO}$ with a concentration of $10 \mu \mathrm{M}$, was $30 \mathrm{~min}$. The Mb assay with ALF795 was repeated using conditions identical to those used by Carmona et al. for the complex $\left[\mathrm{Mo}(\mathrm{CO})_{3}\left(\mathrm{CNCMe}_{2} \mathrm{CO}_{2} \mathrm{H}\right)_{3}\right]$ $($ ALF794; $[\mathrm{Mb}]=10 \mu \mathrm{M}$, [photoCORM] $=10 \mu \mathrm{M}, 4 \mu \mathrm{mg} / \mathrm{mL}$ sodium dithionite). ${ }^{[31]}$ Under these conditions, ALF794 released $0.95 \mathrm{mmol}$ of $\mathrm{CO}$ per mmol of complex after $150 \mathrm{~min}$, with $t_{1 / 2}=$ $49 \mathrm{~min}$, while ALF795 released $1.07 \mathrm{mmol}$ of CO per mmol of complex after $150 \mathrm{~min}$, with $t_{1 / 2}=17 \mathrm{~min}$ (the number of equiv. of CO molecules per molecule of ALF795 is slightly greater than one since the actual concentration of $\mathrm{Mb}$ in the cell was $11 \mu \mathrm{M}$ ). Thus, the rate of $\mathrm{CO}$ release seems to be significantly higher for ALF795. While the lack of methyl substituents in ALF795 could influence the CO release properties, differences in the spectral distributions of the UV lamps used, as well as the irradiance values, may be more important.

The material Zn,Al-ALF795 was tested under the same Mb assay conditions as used for the free photoCORM, with the amount of intercalated $\mathrm{LDH}$ being adjusted to give an equivalent ALF795 concentration of $20 \mu \mathrm{M}$ in the final assay mixture. The $\mathrm{LDH} \mathrm{Zn,Al-NO}$, which has no CO groups, was selected as a negative control. It did not cause any change in the spectrum of
$\mathrm{Mb}$, showing that the concentration of deoxy-Mb was maintained constant. In contrast, the material Zn,Al-ALF795 caused a decrease in the concentration of deoxy-Mb and an increase in the concentration of $\mathrm{Mb}-\mathrm{CO}$, indicating that the photoactivatable properties of the free CORM were retained. The total COrelease reached $1.26 \mathrm{mmol}$ per mmol of complex after $195 \mathrm{~min}$ The initial CO release rate of $0.010 \mathrm{~mol} \mathrm{CO} \cdot \mathrm{mol} \mathrm{CORM}^{-1} \cdot \mathrm{min}^{-1}$ was slightly lower than that observed for the free CORM $(0.017$ $\left.\mathrm{mol} \mathrm{CO} \cdot \mathrm{mol} \mathrm{CORM}^{-1} \cdot \mathrm{min}^{-1}\right)$, and the corresponding half-life was longer (48 $\mathrm{min}$ vs. $30 \mathrm{~min}$ ).

The Mb assay necessarily employs an excess of sodium dithionite to prepare the solution of reduced deoxy-Mb. To evaluate the occurrence or otherwise of dithionite intercalation into the $\mathrm{Zn}, \mathrm{Al}-\mathrm{LDH}$ (by ion exchange) during the assays in HEPES buffer, two experiments were performed in which a portion of the material Zn,Al-ALF795 was suspended in a $0.1 \%$ solution of sodium dithionite in $10 \mathrm{mM}$ HEPES. The suspensions were stirred at $37{ }^{\circ} \mathrm{C}$ for $2 \mathrm{~h}$ - one was maintained in the dark, while the other was irradiated with UV light exactly as performed in the normal $\mathrm{Mb}$ assay. The PXRD patterns and FT-IR spectra of the solids recovered from these two experiments were similar to those for the pristine material Zn,Al-ALF795 (Figure S2 in the Supporting Information). The results indicate that no measurable 
intercalation of dithionite occurred during the two tests and, by extension, during the normal Mb assays with Zn,Al-ALF795.

One of the main drawbacks of using the Mb assay with CORMs is that the dithionite may not be innocent in CO release. McLean et al. showed that the reducing agent greatly facilitated release of $\mathrm{CO}$ from two of the most studied CORMs, $\left[\mathrm{Ru}(\mathrm{CO})_{3} \mathrm{Cl}_{2}\right]_{2}$ (CORM-2) and $\left[\mathrm{Ru}(\mathrm{CO})_{3} \mathrm{Cl}\right.$ (glycinate)] (CORM3). ${ }^{[49]}$ Dithionite has subsequently been shown to enhance $C O$ release from other complexes such as Mn-based CORMs. ${ }^{[50]}$ Hence, the influence of this reducing agent must be assessed whenever the $\mathrm{Mb}$ assay is used to follow $\mathrm{CO}$ release from CORMs. The observation that no conversion of deoxy-Mb to Mb$\mathrm{CO}$ takes place in the dark in the presence of ALF795 indicates that dithionite does not facilitate $\mathrm{CO}$ release from the complex. This was further investigated for both the free CORM and $\mathrm{Zn}, \mathrm{Al}$ ALF795 by incubating the samples in HEPES in the absence of $\mathrm{Mb}$ and dithionite, but with constant irradiation with UV light as performed in the normal $\mathrm{Mb}$ assay. After 15 min dithionitereduced $\mathrm{Mb}$ was added and the absorption spectrum was immediately recorded. For both the free CORM and $\mathrm{Zn}, \mathrm{Al}-$ ALF795 there was an immediate jump in Mb-CO formation $(0.73$ $\mathrm{mmol} \mathrm{CO}$ and $0.44 \mathrm{mmol} \mathrm{CO}$ per mmol of complex, respectively), followed by a slower release over the next $75 \mathrm{~min}$, leading to 1.0 equiv. of $\mathrm{CO}$ per molecule of free CORM, and 0.94 equiv. of $\mathrm{CO}$ per molecule of intercalated CORM. Thus, CO is released from ALF795 during a 15 min incubation in HEPES with UV irradiation. To explore the effect of dithionite alone,$^{[49]}$ free ALF795 $(20 \mu \mathrm{M})$ was incubated in HEPES in the dark with excess dithionite for 10 min, after which $43 \mu \mathrm{M} \mathrm{Mb}$ was added. An absorption spectrum was immediately recorded and showed no Mb-CO formation. No $\mathrm{Mb}-\mathrm{CO}$ formed after keeping this mixture in the dark for a further $30 \mathrm{~min}$. The UV lamp was then turned on and irradiation was performed for $30 \mathrm{~min}$, leading to $11 \mu \mathrm{M} \mathrm{Mb}-\mathrm{CO}$, which matches the $\mathrm{Mb}-\mathrm{CO}$ yield obtained in the normal $\mathrm{Mb}$ assay where ALF795, Mb and dithionite were added together. These results suggest that only UV irradiation is responsible for initiating CO release from ALF795, and that this process is not enhanced by dithionite.

With the aim of analyzing the ability of the Zn,Al-LDH host matrix to trap ALF795 and decarbonylation fragments inside its interlamellar regions, the leaching of Mo from Zn,Al-ALF795 was evaluated in HEPES solution by inductively coupled plasma optical emission spectrometry (ICP-OES). The results revealed that only $2 \%$ Mo leaching occurred after $5 \mathrm{~h}$ incubation at $37^{\circ} \mathrm{C}$ with UV light irradiation. Thus, the material Zn,Al-ALF795 behaves as a true photoCORMA under these conditions. The capacity of the layered host matrix to retain the Mo fragments compares favorably with that reported for a zinc-based MOF hosting ALF794, which underwent $17 \%$ Mo leaching after incubation in HEPES for $6 \mathrm{~h}$ at $37^{\circ} \mathrm{C} \cdot{ }^{[31]}$ After the leaching test with Zn,Al-ALF795, the recovered solid (denoted Zn,AlALF795L) was characterized by FTIR spectroscopy and PXRD (Figures 1 and 3). The IR spectrum of Zn,Al-ALF795L is similar to that for Zn,Al-ALF795 except for a slight decrease in the relative intensities of the $v(C O)$ bands. The PXRD pattern shows that the $16 \AA$ intercalated phase was retained, albeit with a slight lowering of crystallinity.
The results presented so far show that the material $\mathrm{Zn}, \mathrm{Al}-$ ALF795 behaves as a real photoCORMA with attractive CO release characteristics, chief among which is the relatively high amount of $\mathrm{CO}$ released under the conditions of the $\mathrm{Mb}$ assay, corresponding to about $1 \mathrm{mmol}$ per gram of material. For comparison, the ALF794@Zn-MOF mentioned above was shown to release a total amount of $0.09 \mathrm{mmol}$ per gram. The high dosage of CO released by Zn,Al-ALF795 is a consequence of the high CORM loading coupled with the retention of the photoactivatable properties of the tricarbonyl complex.

\section{CO release monitored by gas chromatography}

Photoactivated CO release from ALF795 and Zn,Al-ALF795 in the absence of $\mathrm{Mb}$ was followed by online GC. While the assay volume (ca. $3 \mathrm{~mL}$ ), buffer solution (10 $\mathrm{mM} \mathrm{HEPES)} \mathrm{and}$ temperature $\left(37^{\circ} \mathrm{C}\right)$ were maintained constant with respect to the $\mathrm{Mb}$ assay, much higher quantities of CORM had to be used with this detection method, corresponding to an effective Mo concentration of about $50 \mathrm{mM}$. For the intercalated and free CORM, no CO release was detected before UV irradiation $(\lambda=$ $365 \mathrm{~nm}, 7 \mathrm{~mW} \mathrm{~cm}^{-2}$ ) was initiated. Upon irradiation, the amount of $\mathrm{CO}$ released from $\mathrm{Zn}, \mathrm{Al}-\mathrm{ALF} 795$ initially increased up to ca. $40 \mathrm{~min}$, after which $\mathrm{CO}$ liberation slowed down and reached undetectable limits after ca. $4.4 \mathrm{~h}$ (Figure 7). The total amount of $\mathrm{CO}$ released was $0.29 \mathrm{mmol}$ per mmol of complex. Although no $\mathrm{CO}$ release was detected between $4.4 \mathrm{~h}$ and $24 \mathrm{~h}$, CO release below the detection limit during this period could have amounted to $0.07 \mathrm{mmol}$ per mmol of complex. While the overall time course of $\mathrm{CO}$ release in the $\mathrm{GC}$ assay is similar to that observed with the Mb assay for Zn,Al-ALF795, with a plateau being reached after about $3 \mathrm{~h}$, the former detected a lower total amount of released CO. Despite the fact that different UV light sources were used in these assays, the irradiance values at the samples were roughly similar $\left(7-8 \mathrm{~mW} \mathrm{~cm}^{-2}\right)$. The lower amount of $\mathrm{CO}$ released in the GC assay may be because photoactivation was hindered due to: (i) the use of a standard borosilicate glass reaction flask (rather than a quartz cuvette as used in the Mb assay); (ii) lower light penetration caused by the much higher amount of photoCORMA (200 mg) used, which formed a suspension with the buffer solution.

After the GC assay, the solid (denoted Zn,Al-ALF795GC) was recovered by centrifugation and characterized by PXRD and FTIR spectroscopy. The results were similar to those obtained for the recovered material Zn,Al-ALF795L, showing a slight decrease in the relative intensities of the $v(\mathrm{CO})$ bands in the IR spectrum, and the retention of the $16 \AA$ expanded LDH phase, albeit with a lower crystallinity when compared with the as-synthesized material Zn,Al-ALF795 (Figures 1 and 3).

For free ALF795 tested under identical conditions to Zn,AlALF795 at $37^{\circ} \mathrm{C}$, similar kinetic behavior was observed, albeit with a higher amount of $\mathrm{CO}$ being released (Figure 7). Initially, the rate of $\mathrm{CO}$ release was relatively high, reaching a maximum at ca. $25 \mathrm{~min}$, and then decreased up to $9.6 \mathrm{~h}$, after which no further $\mathrm{CO}$ was detected (up to $24 \mathrm{~h}$ ). The total amount of $\mathrm{CO}$ released was $1.01 \mathrm{mmol}$ per mmol of complex, which is only 
about $30 \%$ lower than the total amount measured in the $\mathrm{Mb}$ assay.

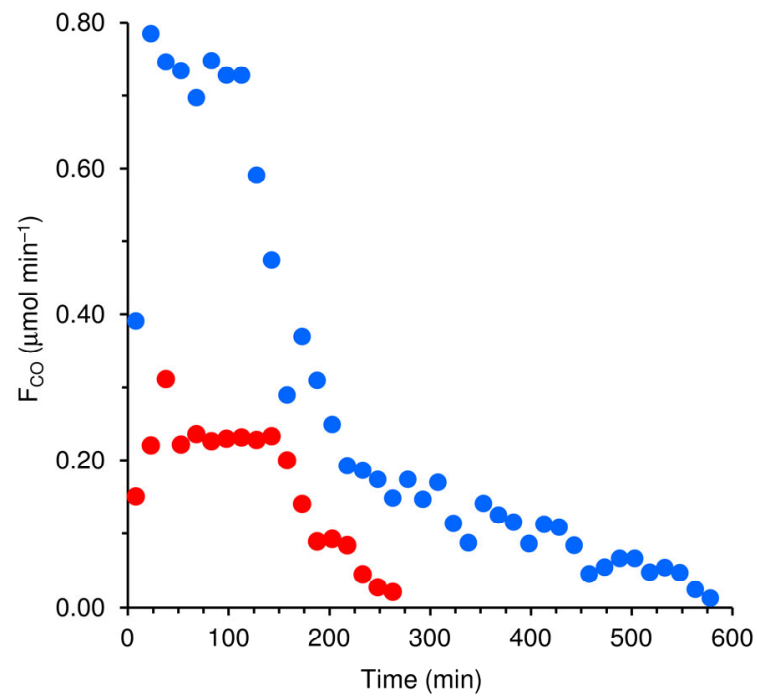

Figure 7. GC assays of ALF795 (blue circles) and Zn,Al-ALF795 (red circles) under UV irradiation. Shown is a time course of the molar flow rate of CO.

After the assays had been run for $24 \mathrm{~h}$, excess hydrogen peroxide was added to the reactor (initial $\mathrm{H}_{2} \mathrm{O}_{2} / \mathrm{Mo}$ molar ratio $=$ 6) to study oxidative decarbonylation of the remaining molybdenum carbonyl fragments. This reaction is highly relevant since many diseased cells, such as inflamed cells and cancer cells, show a sustained increase in intrinsic generation of ROS such as $\mathrm{H}_{2} \mathrm{O}_{2}$. Hence, intracellular $\mathrm{H}_{2} \mathrm{O}_{2}$-triggered $\mathrm{CO}$ release from CORMs is seen as a potentially viable mechanism for targeted CO delivery. ${ }^{[51,52]}$

Under the oxidizing conditions, $\mathrm{CO}$ was partially oxidized to $\mathrm{CO}_{2}$. Figure 8 depicts the total $\mathrm{CO}+\mathrm{CO}_{2}$ (denoted $\mathrm{CO}_{x}$ ) molar flow rates as a function of time. For Zn,Al-ALF795, the $\mathrm{CO}_{x}$ flow rate peaked at a high value immediately following addition of $\mathrm{H}_{2} \mathrm{O}_{2}$, and then decreased rapidly with time until no measurable amounts could be detected after $3.5 \mathrm{~h}$. The total amount of $\mathrm{CO}_{x}$ released was $1.89 \mathrm{mmol}$ per mmol of complex, and the $\mathrm{CO} / \mathrm{CO}_{2}$ molar ratio was 0.59 . For the free CORM, the rate of $\mathrm{CO}_{x}$ liberation increased with time, reaching a maximum at ca. $30 \mathrm{~min}$, and then decreased until no measurable amounts could be detected after $2.8 \mathrm{~h}$. The total amount of $\mathrm{CO}_{x}$ released was $1.88 \mathrm{mmol}$ per $\mathrm{mmol}$ of complex, and the $\mathrm{CO} / \mathrm{CO}_{2}$ molar ratio was 2.53 .

A control experiment was carried out with the nitrate-form $\mathrm{LDH} \mathrm{Zn}, \mathrm{Al}-\mathrm{NO}_{3}$ to check the ability of the $\mathrm{Zn}, \mathrm{Al}$ double hydroxide layers to decompose $\mathrm{H}_{2} \mathrm{O}_{2}$. lodometric titration showed a relatively low $\mathrm{H}_{2} \mathrm{O}_{2}$ decomposition of $9 \%$ (giving $\mathrm{O}_{2}$ and $\mathrm{H}_{2} \mathrm{O}$ ) after incubating the mixture of excess $\mathrm{H}_{2} \mathrm{O}_{2}$ and LDH in HEPES for $5 \mathrm{~h}$ at $37^{\circ} \mathrm{C}$.

The summed $\mathrm{CO}_{x}$ amounts from the two sequential GC assays, i.e. photo-release of $\mathrm{CO}$ followed by $\mathrm{H}_{2} \mathrm{O}_{2}$-triggered $\mathrm{CO} / \mathrm{CO}_{2}$ liberation, were $2.18 \mathrm{mmol} \mathrm{CO}_{x}$ per mmol of complex for $\mathrm{Zn}, \mathrm{Al}-\mathrm{ALF} 795$, and $2.89 \mathrm{mmol} \mathrm{CO}_{x}$ per mmol of complex for
ALF795. Hence, the carbon balance was almost closed for ALF795 at $96 \%$, while there was a deficit of $27 \%$ for $\mathrm{Zn}, \mathrm{Al}$ ALF795. The ATR IR spectrum of the solid recovered after the two sequential assays with Zn,Al-ALF795 showed complete loss of the $\mathrm{v}(\mathrm{CO})$ bands and almost complete loss of the $\mathrm{v}(\mathrm{CN})$ bands, while the PXRD pattern showed that the original $16 \AA$ phase (which, as mentioned above, was largely retained after the $24 \mathrm{~h}$ photodecarbonylation step) had been destroyed by the $\mathrm{H}_{2} \mathrm{O}_{2}$ treatment to give a very poorly crystalline LDH phase with a basal spacing of about $9.5 \AA$ (Figure S3 in the Supporting Information). As expounded in the Supporting Information, several new bands in the IR spectrum of the recovered solid between 1200 and $1800 \mathrm{~cm}^{-1}$ can be attributed to intercalated glycinate anions formed by the aqueous peroxide-promoted hydrolysis of the isocyanoacetate ligands. The data suggest that this transformation is accompanied by the release of oxidized Mo-containing species into solution. The failure to quantify three equivalents of released $\mathrm{CO}$ over the two sequential assays may be partly due to solubilization of $\mathrm{CO}_{x}$ in the liquid phase, formation and trapping of carbonate species by the LDH, and continued $\mathrm{CO}_{x}$ release with time in amounts below the GC-TCD detection limits.

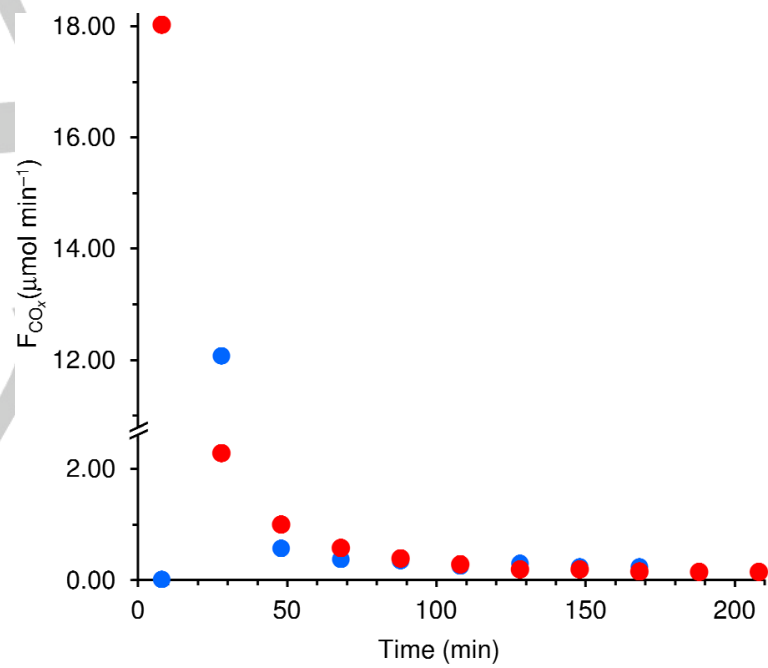

Figure 8. GC assays of ALF795 (blue circles) and Zn,Al-ALF795 (red circles) to study oxidative decarbonylation with $\mathrm{H}_{2} \mathrm{O}_{2}$. After the normal assay with UV light-induced $\mathrm{CO}$ release (Figure 7) had been run for $24 \mathrm{~h}$, excess $\mathrm{H}_{2} \mathrm{O}_{2}$ was added to the reactors (time zero in this plot), and the time course of the molar flow rate of $\mathrm{CO}_{x}\left(\mathrm{CO}+\mathrm{CO}_{2}\right)$ was followed.

\section{Conclusions}

In the present work, we demonstrated that layered double hydroxides can be used as a carrier system for the photoCORM $\left[\mathrm{Mo}(\mathrm{CO})_{3}\left(\mathrm{CNCH}_{2} \mathrm{COOH}\right)_{3}\right](\mathrm{ALF} 795)$. Although a few examples of metal carbonyl-intercalated LDHs have been reported previously, this is the first case where such a material has been studied from the CORM perspective. The trianionic complex appears to be an ideal match with the $\mathrm{Zn}_{2} \mathrm{Al}-\mathrm{LDH}$ host, selfassembling during the coprecipitation synthesis to form a close- 
packed monolayer array between the host $\mathrm{Zn}, \mathrm{Al}$ layers. The perfect host-guest complementarity permits a high ALF795 loading of $0.82 \mathrm{mmol} \mathrm{g}^{-1}$, which corresponds to a CO payload of $2.46 \mathrm{mmol} \mathrm{g}^{-1}$. The photoactivatable properties of the tricarbonyl complex are largely retained in the intercalate, with the $\mathrm{Mb}$ assay showing a CO releasing efficiency of $42 \%$ (based on the three $\mathrm{CO}$ ligands per complex), which is only slightly lower than that observed for pristine ALF795 (ca. 50\%). Intercalation of the complex in the LDH had an appreciable effect on the kinetics of CO release, with a ca. $50 \%$ increase in the half-life value determined by the Mb assay. A major advantage of the hostguest composite Zn,Al-ALF795 is its resistance to leaching of molybdenum fragments (both loaded ALF795 and decarbonylated photoproduct(s)) under simulated physiological conditions (HEPES, $37^{\circ} \mathrm{C}$ ). We conclude that LDHs should be a focus of future research on the development of biocompatible photoCORMAs.

\section{Experimental Section}

Materials and methods: The chemicals $\mathrm{Mo}(\mathrm{CO})_{6}$ (Fluka), cycloheptatriene $(95 \%)$, ethyl isocyanoacetate $(98 \%$, Alfa Aesar), anhydrous THF (99.9\%), dichloromethane (99.9\%), hexane (99\%), ethyl acetate $(99.5 \%$, Riedel de Häen), sodium hydroxide, sulfuric acid (95\%), zinc nitrate hexahydrate (99\%, Fluka), aluminium nitrate nonahydrate (98.5\%, Riedel-de-Haën), $1 \mathrm{M}$ sodium hydroxide (Fluka), myoglobin from equine heart $\geq 90 \%$ (SDS-PAGE), sodium dithionite, phosphate buffered saline tablet, 4-(2-hydroxyethyl)piperazine-1-ethanesulfonic acid (HEPES $99.5 \%)$, and dry dimethylsulfoxide (99.9\%, Panreac) were purchased from Sigma-Aldrich unless otherwise stated, and used as received.

When appropriate, preparations and manipulations were carried out under a dry nitrogen atmosphere with standard Schlenk techniques. Solvents were dried using standard protocols (THF over $\mathrm{Na} /$ benzophenone, $\mathrm{CH}_{2} \mathrm{Cl}_{2}$ and hexane over $\mathrm{CaH}_{2}$, ethyl acetate over $\mathrm{Na}_{2} \mathrm{SO}_{4}$ ), distilled and degassed prior to use. A nitrate-form $\mathrm{Zn}, \mathrm{Al}-\mathrm{LDH}$ (denoted $\mathrm{Zn}, \mathrm{Al}-\mathrm{NO}_{3}$ ) with the composition $\mathrm{Zn}_{4} \mathrm{Al}_{2}(\mathrm{OH})_{12}\left(\mathrm{NO}_{3}\right)_{2} \cdot 2.5 \mathrm{H}_{2} \mathrm{O}$ was prepared by using the standard method of coprecipitation of the $\mathrm{Zn}^{2+}$ and $\mathrm{Al}^{3+}$ hydroxides (initial $\mathrm{Zn}^{2+} / \mathrm{Al}^{3+}$ molar ratio in solution $=2$ ) in the presence of nitrate ions at a constant $\mathrm{pH}$ of 7.5-8 under nitrogen, followed by aging of the gel at $80{ }^{\circ} \mathrm{C}$ for $20 \mathrm{~h} \cdot{ }^{[42,53]}$ Literature methods were used to prepare $\left[\mathrm{Mo}(\mathrm{CO})_{3}\left(\eta^{6}-\mathrm{C}_{7} \mathrm{H}_{8}\right)\right]^{[54]}$ and $\left[\mathrm{Mo}(\mathrm{CO})_{3}\left(\mathrm{CNCH}_{2} \mathrm{COOH}\right)_{3}\right](\mathrm{ALF} 795) \cdot{ }^{[45]}$

Physical measurements: Microanalyses for $\mathrm{C}, \mathrm{H}$ and $\mathrm{N}$ were carried out with a Truspec Micro CHNS 630-200-200 elemental analyzer. SEM images, EDS analyses and elemental mapping images were collected on a Hitachi SU-70 microscope equipped with a Bruker Quantax 400 detector operating at $15 \mathrm{kV}$. Samples were prepared by deposition on aluminium sample holders followed by carbon coating using an Emitech K 950 carbon evaporator. ICP OES/mass spectrometry analyses were performed according to ISO 11885/17294 standards using Jobin Yvon Activa $\mathrm{M}$ and Thermo $\mathrm{X}$ Series spectrometers at the Central Analysis Laboratory, University of Aveiro. PXRD data were collected at ambient temperature using a Malvern PANalytical Empyrean instrument equipped with a PIXcel 1D detector set at $240 \mathrm{~mm}$ from the sample, in a BraggBrentano para-focusing optics configuration, with a spinning flat-plate sample holder. Cu-K $\mathrm{K}_{\alpha 1,2} \mathrm{X}$-radiation $\left(\lambda_{1}=1.540598 \AA ; \lambda_{2}=1.544426 \AA\right)$ filtered with a nickel foil was used, with the X-ray tube operating at $45 \mathrm{kV}$ and $40 \mathrm{~mA}$. Samples were step scanned in $0.02^{\circ} 2 \theta$ steps with a counting time of $100-200 \mathrm{~s}$ per step and analyzing an angular range of 3$70^{\circ} 2 \theta$. FTIR spectra ( $\mathrm{KBr}$ pellets) were obtained using a Mattson- 7000 spectrophotometer. Attenuated total reflectance (ATR) FT-IR spectra were recorded on the same instrument equipped with a Specac Golden Gate Mk II ATR accessory having a diamond top-plate and KRS-5 focussing lenses. Solid-state NMR spectra were recorded on a Bruker Avance III HD $700 \mathrm{MHz}$ spectrometer. ${ }^{13} \mathrm{C}\left\{{ }^{1} \mathrm{H}\right\}$ CP MAS NMR spectra were recorded at $176.048 \mathrm{MHz}$ with $2.6 \mu \mathrm{s}{ }^{1} \mathrm{H} 90^{\circ}$ pulses, an $8 \mathrm{~ms}$ contact time, a spinning rate of $12 \mathrm{kHz}$ and $4 \mathrm{~s}$ recycle delays. Chemical shifts are quoted in ppm relative to TMS. The UV-Vis spectra were collected using a GBC UV-Vis 918 Cintral spectrophotometer. UV lamp powers were measured with a thermal power sensor (ThorLabs, thermopile-S310C) coupled to an optical power and energy meter (Thorlabs, PM100D). The distance between the sensor and the lamp was $5 \mathrm{~cm}$, as used in the normal assays.

Synthesis of Zn,Al-ALF795: A solution of the sodium salt $\mathrm{Na} 3\left[\mathrm{Mo}(\mathrm{CO})_{3}\left(\mathrm{CNCH}_{2} \mathrm{COO}\right)_{3}\right]$ was prepared by addition of 3 equivalents of $\mathrm{NaOH}$ to an aqueous suspension $(60 \mathrm{~mL})$ of ALF795 $(0.44 \mathrm{~g}, 1.01 \mathrm{mmol})$. A solution of $\mathrm{Zn}\left(\mathrm{NO}_{3}\right)_{2} \cdot 6 \mathrm{H}_{2} \mathrm{O}(1.19 \mathrm{~g}, 3.99 \mathrm{mmol})$ and $\mathrm{Al}\left(\mathrm{NO}_{3}\right)_{3} \cdot 9 \mathrm{H}_{2} \mathrm{O}$ $(0.75 \mathrm{~g}, 1.99 \mathrm{mmol})$ in decarbonated deionized (DD) water $(60 \mathrm{~mL})$ was then added dropwise and the $\mathrm{pH}$ of the mixture was maintained between 7.5 and 8 using $0.2 \mathrm{M} \mathrm{NaOH}$. After the addition was complete, the reaction mixture was aged at $65{ }^{\circ} \mathrm{C}$ for $20 \mathrm{~h}$. The resultant pale cream precipitate was filtered, washed with DD water $(4 \times 50 \mathrm{~mL})$, and vacuumdried. Anal. Calcd for $\mathrm{Zn}_{4} \mathrm{Al}_{2}(\mathrm{OH})_{12}\left(\mathrm{Mo}(\mathrm{CO})_{3}\left(\mathrm{CNCH}_{2} \mathrm{COO}\right)_{3}\right)_{0.667} \cdot 3.5 \mathrm{H}_{2} \mathrm{O}$ (870.9): C, 11.03; H, 2.66; N, 3.22. Found: C, 10.92; H, 2.94; N, 3.36. EDS gave an average $\mathrm{Zn} / \mathrm{Al}$ ratio of $2.0 \pm 0.1$ and an average $\mathrm{Al} / \mathrm{Mo}$ ratio of $3.0 \pm 0.1$. FT-IR $\left(\mathrm{KBr}, \mathrm{cm}^{-1}\right): \tilde{v}=3415(\mathrm{br}), 2181(\mathrm{~s}, \mathrm{v}(\mathrm{C} \equiv \mathrm{N})), 2148$ (vs, $\mathrm{v}(\mathrm{C} \equiv \mathrm{N})), 1936$ (vs, v(CO)), 1854 (vs, $v(\mathrm{CO})), 1612\left(\mathrm{~s}, \mathrm{vas}\left(\mathrm{CO}_{2}^{-}\right)\right), 1425$ $(\mathrm{w}), 1386\left(\mathrm{~s}, v_{\mathrm{s}}\left(\mathrm{CO}_{2}^{-}\right)\right), 1298(\mathrm{~s}), 974(\mathrm{w}), 903(\mathrm{w}), 805(\mathrm{w}), 704(\mathrm{w}), 615$ (sh), $592(\mathrm{~m}), 425(\mathrm{~m}) \cdot{ }^{13} \mathrm{C}\left\{{ }^{1} \mathrm{H}\right\}$ CP MAS NMR: $\delta=214.2(\mathrm{C} \equiv \mathrm{O}), 171.5$ $\left(\mathrm{C} \equiv \mathrm{NCH}_{2}\right), 158.5(\mathrm{COO}), 47.3\left(\mathrm{C} \equiv \mathrm{NCH}_{2}\right)$.

Stability of Zn,Al-ALF795 in buffer solutions: The material Zn,AlALF795 $(0.04 \mathrm{~g})$ was incubated in $10 \mathrm{mM}(\mathrm{pH} 7.4)$ PBS or HEPES buffer solutions $(20 \mathrm{~mL})$ for $3 \mathrm{~h}$ at $37{ }^{\circ} \mathrm{C}$. The resultant solid was filtered and vacuum-dried at room temperature for $2 \mathrm{~h}$. Both materials, denoted $\mathrm{Zn}, \mathrm{Al}-\mathrm{ALF795P}$ and $\mathrm{Zn}, \mathrm{Al}-\mathrm{ALF795H}$, were characterized by FTIR spectroscopy and PXRD.

Determination of $\mathrm{CO}$ release by the $\mathrm{Mb}$ assay: $\mathrm{CO}$ release from the complex ALF-795 and the material Zn,Al-ALF795 was quantified by the $\mathrm{Mb}$ assay. ${ }^{[48]}$ This method monitors the change in the Q-band region of the absorption spectrum of deoxy-Mb vs. Mb-CO. Deoxy-Mb was obtained by reducing met-myoglobin (met-Mb) with sodium dithionite $\left(\mathrm{Na}_{2} \mathrm{~S}_{2} \mathrm{O}_{4}\right)$. The lowering of the oxidation state associated with the met$\mathrm{Mb}$ to deoxy-Mb conversion manifests itself as a color change from light brown to pale red. The $\mathrm{CO}$ liberated from the $\operatorname{CORM}(\mathrm{A})$ binds to deoxy$\mathrm{Mb}$ and thus the absorption maximum of deoxy-Mb at $557 \mathrm{~nm}$ decreases while those of $\mathrm{Mb}-\mathrm{CO}$ at 540 and $577 \mathrm{~nm}$ increase. The increase in the concentration of $\mathrm{Mb}-\mathrm{CO}$ in solution can be visually confirmed by an intensification of the red color.

Stock solutions/dispersions of $\mathrm{Mb}, \mathrm{Na}_{2} \mathrm{~S}_{2} \mathrm{O}_{4}$ and the material $\mathrm{Zn}, \mathrm{Al}-$ ALF795 were freshly prepared in degassed $10 \mathrm{mM}$ HEPES buffer. A stock solution of the complex ALF-795 was prepared in degassed DMSO or HEPES. First, the stock solution of $\mathrm{Mb}$ from equine heart was reduced by adding $1 \mathrm{~mL}$ of the stock solution of $\mathrm{Na}_{2} \mathrm{~S}_{2} \mathrm{O}_{4}(10 \mathrm{mg} / \mathrm{mL})$ to give a final $\mathrm{Na}_{2} \mathrm{~S}_{2} \mathrm{O}_{4}$ content of $0.1 \%$. An aliquot of the resultant deoxy-Mb solution $(2970 \mu \mathrm{L})$ and solution/dispersion $(30 \mu \mathrm{L})$ of complex ALF-795 or material Zn,Al-ALF795 were added to a sealed quartz cuvette (pathlength $1 \mathrm{~cm}$ ). The amounts of ALF-795 and Zn,Al-ALF795 were calculated to give a final CORM concentration of $20 \mu \mathrm{M}$. All the steps were carried out under a dry nitrogen atmosphere to prevent oxidation. The sealed cuvette was either kept in the dark or irradiated with UV light $(\lambda=365 \mathrm{~nm})$ using a $9 \mathrm{~W}$ Lidan U-type lamp positioned $5 \mathrm{~cm}$ from the 
cuvette $\left(8 \mathrm{~mW} \mathrm{~cm}^{-2}\right)$. The illumination was interrupted in intervals of 15 min to measure absorption spectra between 500 and $600 \mathrm{~nm}$, with a scan speed of $200 \mathrm{~nm} / \mathrm{min}$ and a slit width of $2 \mathrm{~nm}$. Experiments were performed at $37{ }^{\circ} \mathrm{C}$ over a period of $5 \mathrm{~h}$. Two controls were performed: the first comprising a spectrum of only deoxy-Mb $(0 \% \mathrm{Mb}-\mathrm{CO})$, and the second comprising a spectrum of $100 \% \mathrm{Mb}-\mathrm{CO}$ which was obtained by bubbling $\mathrm{CO}$ though the deoxy-Mb solution for $10 \mathrm{~min}$. The actual concentration of $\mathrm{Mb}$ in the cuvette for each assay was calculated from the maximal absorption peak of the Mb-CO solution at $540 \mathrm{~nm}(\varepsilon=15.4$ $\mathrm{mM}^{-1} \mathrm{~cm}^{-1}$ ); $[\mathrm{Mb}]=37-41 \mu \mathrm{M}$. All assays were carried out in triplicate. The spectroscopic data were treated in the standard way by applying a correction at one isosbestic point $(510 \mathrm{~nm}){ }^{[48]}$

GC studies of $\mathrm{CO} / \mathrm{CO}_{2}$ release: The solid molybdenum-containing compound (200 mg Zn,Al-ALF795 or 66 mg complex ALF795, equivalent to $152 \mu \mathrm{mol} \mathrm{Mo}$ ) was added to a pear-shaped borosilicate glass reactor containing a magnetic stirring bar (for stirring at $1000 \mathrm{rpm}$ ), and subsequently the system was purged with $\mathrm{He}$. Then, $3 \mathrm{~mL}$ of previously degassed $10 \mathrm{mM}$ HEPES solution and $300 \mu \mathrm{L}$ of $\mathrm{Na}_{2} \mathrm{~S}_{2} \mathrm{O}_{4}(10 \mathrm{mg} / \mathrm{mL})$ were added through an inlet with septum, using a gas-tight syringe. The reactor was equipped with a soldered reflux condenser to avoid evaporation; cooling was accomplished using an external circulating bath (Lab. Companion RW-0525G) with a temperature set point of $-5^{\circ} \mathrm{C}$. The reaction vessel was immersed in a temperature-controlled bath at $37^{\circ} \mathrm{C}$ and fed with a He flow $\left(6 \mathrm{~mL} \mathrm{~min}^{-1}\right)$, which was bubbled through the liquid phase, exiting the reactor through the reflux condenser which was online-connected to a Varian CP-3800 GC. The GC was equipped with a thermal conductivity detector (TCD), a semi-capillary CarboPLOT P7 column (15 $\mathrm{m} \times 530 \mu \mathrm{m}$ (ID), $25 \mu \mathrm{m}$ film thickness) and a six-port $\mathrm{VICl}$ gas-sampling valve possessing a $250 \mu \mathrm{L}$ loop (for online sampling), with $\mathrm{He}$ as carrier gas. The amounts of $\mathrm{CO}$ and $\mathrm{CO}_{2}\left(\mathrm{CO}_{\mathrm{x}}=\mathrm{CO}+\mathrm{CO}_{2}\right)$ released were determined by an external calibration method and integration of the curves of molar flow rate $(\mathrm{F})$ vs. time of $\mathrm{CO}$ or $\mathrm{CO}_{x}$ release. The detection limits were ca. 2 and $10 \mu \mathrm{M}$ for $\mathrm{CO}$ and $\mathrm{CO}_{2}$, respectively. Irradiation with UV light $(\lambda=365 \mathrm{~nm})$ was performed using a $15 \mathrm{~W}$ Velleman spiral-type lamp positioned $5 \mathrm{~cm}$ from the reactor $(7 \mathrm{~mW}$ $\mathrm{cm}^{-2}$ ). The effluent gas was analyzed in intervals of $15 \mathrm{~min}$, considering as initial instant the moment that UV irradiation was initiated (no CO release was detected without irradiation). The GC analysis delay time was $8 \mathrm{~min}$ for the effluent gas to reach the gas sampling valve. After the an assay with Zn,Al-ALF795 (24 h), the solid (denoted Zn,Al-ALF795GC) was recovered by centrifugation, washed with acetone and vacuum-dried and characterized by PXRD and FTIR spectroscopy.

For both the free CORM and Zn,Al-ALF795, additional assays were performed in which UV irradiation for $24 \mathrm{~h}$ was followed by addition of aqueous $\mathrm{H}_{2} \mathrm{O}_{2}(900 \mu \mathrm{mol})$ to the reactors to obtain an initial $\mathrm{H}_{2} \mathrm{O}_{2} / \mathrm{Mo}$ molar ratio of 6 . The $\mathrm{CO}_{x}\left(\mathrm{CO}+\mathrm{CO}_{2}\right)$ release was monitored in intervals of $20 \mathrm{~min}$, considering as initial instant the moment that the oxidant was added to the reactor, and an analysis delay time of $8 \mathrm{~min}$.

Leaching studies: To investigate the capacity of the LDH host matrix to securely trap the complex ALF-795 and possible decarbonylation products, a suspension of Zn,Al-ALF795 (0.02 g) in $10 \mathrm{mM}$ HEPES (3 $\mathrm{mL}$ ) was prepared. The suspension was then kept at $37^{\circ} \mathrm{C}$ under UV light irradiation $(\lambda=365 \mathrm{~nm}$, lamp-to-cuvette distance $5 \mathrm{~cm}$ ) for $5 \mathrm{~h}$. After this period the solid was collected by filtration, and the supernatant was further filtered through a $0.2 \mu \mathrm{m}$ nylon filter membrane. The solid, denoted Zn,Al-ALF795L, was characterized by FTIR spectroscopy and PXRD, while the Mo content in the filtered solution was determined by ICP-OES.

\section{Acknowledgments}

We acknowledge funding provided within the project CICECOAveiro Institute of Materials, UIDB/50011/2020 \& UIDP/50011/2020, and the CENTRO 2020 Regional Operational Programme (project references CENTRO-01-0145-FEDER028031 and PTDC/QUI-QOR/28031/2017), financed by national funds through the FCT (Fundação para a Ciência e a Tecnologia)/MEC (Ministério da Educação e Ciência) and when appropriate co-financed by the European Union through the European Regional Development Fund under the Portugal 2020 Partnership Agreement. The position held by S.M.B. was funded by national funds (OE), through FCT, I.P., in the scope of the framework contract foreseen in the numbers 4,5 and 6 of article 23 of the Decree-Law 57/2016 of 29 August, changed by Law $57 / 2017$ of 19 July.

Keywords: Molybdenum • Carbon monoxide $\cdot$ Isocyanide ligands $\cdot$ Drug delivery $\bullet$ Layered compounds

[1] C. Peers, D.S. Steele, J. Mol. Cell. Cardiol. 2012, 52, 359-365.

[2] G.L. Sternbach, J. Varon, Resuscitation 2003, 58, 127-130.

[3] T. Sjöstrand, Nature 1949, 164, 580-581.

[4] S.H. Heinemann, T. Hoshi, M. Westerhausen, A. Schiller, Chem. Commun. 2014, 50, 3644-3660.

[5] X. Li, K. Damera, Y. Zheng, B. Yu, L.E. Otterbein, B. Wang, J. Pharm Sci. 2016, 105, 406-416.

[6] R. Motterlini, L.E. Otterbein, Nat. Rev. Drug Discov. 2010, 9, 728-743.

[7] H. Yan, J. Du, S. Zhu, G. Nie, H. Zhang, Z. Gu, Y. Zhao, Small 2019, 15, article no. 1904382; doi:10.1002/smll.201904382.

[8] K. Ling, F. Men, W.-C. Wang, Y.-Q. Zhou, H.-W. Zhang, D.-W. Ye, J. Med. Chem. 2018, 61, 2611-2635.

[9] C.C. Romão, W.A. Blättler, J.D. Seixas, G.J.L. Bernardes, Chem. Soc. Rev. 2012, 41, 3571-3583.

[10] S. García-Gallego, G.J.L. Bernardes, Angew. Chem. Int. Ed. 2014, 53, 9712-9721.

[11] J. E. Clark, P. Naughton, S. Shurey, C. J. Green, T. R. Johnson, B. E. Mann, R. Foresti, R. Motterlini, Circ. Res. 2003, 93, e2-e8.

[12] M.A. Wright, J.A. Wright, Dalton Trans. 2016, 45, 6801-6811.

[13] P.C. Ford, Coord. Chem. Rev. 2018, 376, 548-564.

[14] N.S. Sitnikov, Y. Li, D. Zhang, B. Yard, H.-G. Schmalz, Angew. Chem. Int. Ed. 2015, 54, 12314-12318.

[15] H. Inaba, K. Fujita, T. Ueno, Biomater. Sci. 2015, 3, 1423-1438.

[16] D. Nguyen, C. Boyer, ACS Biomater. Sci. Eng. 2015, 1, 895-913.

[17] I. Chakraborty, P.K. Mascharak, Microporous Mesoporous Mater. 2016 , 234, 409-419

[18] A.C. Kautz, P.C. Kunz, C. Janiak, Dalton Trans. 2016, 45, 18045-18063

[19] M. Faizan, N. Muhammad, K.U.K. Niazi, Y. Hu, Y. Wang, Y. Wu, H. Sun, R. Liu, W. Dong, W. Zhang, Z. Gao, Materials 2019, 12, article no. 1643, doi:10.3390/ma12101643

[20] U. Hasegawa, A.J. van der Vlies, E. Simeoni, C. Wandrey, J.A. Hubbell, J. Am. Chem. Soc. 2010, 132, 18273-18280.

[21] G. Dördelmann, T. Meinhardt, T. Sowik, A. Krueger, U. Schatzschneider, Chem. Commun. 2012, 48, 11528-11530.

[22] G. Dördelmann, H. Pfeiffer, A. Birkner, U. Schatzschneider, Inorg Chem. 2011, 50, 4362-4367.

[23] P.C. Kunz, H. Meyer, J. Barthel, S. Sollazzo, A.M. Schmidt, C. Janiak, Chem. Commun. 2013, 49, 4896-4898.

[24] M.A. Gonzales, H. Han, A. Moyes, A. Radinos, A.J. Hobbs, N. Coombs, S.R.J. Oliver, P K. Mascharak, J Mater Chem. B 2014, 2, 2107-2113. 
[25] F. J. Carmona, I. Jiménez-Amezcua, S. Rojas, C. C. Romão, J.A.R. Navarro, C.R. Maldonado, E. Barea, Inorg. Chem. 2017, 56, 1047410480.

[26] Q. He, D.O. Kiesewetter, Y. Qu , X. Fu, J. Fan, P. Huang, Y. Liu, G. Zhu, Y. Liu, Z. Qian, X. Chen, Adv. Mater. 2015, 27, 6741-6746.

[27] C. Bohlender, S. Gläser, M. Klein, J. Weisser, S. Thein, U. Neugebauer, J. Popp, R. Wyrwa, A. Schiller, J. Mater. Chem. B 2014, 2, 1454-1463.

[28] M. Ma, H. Noei, B. Mienert, J. Niesel, E. Bill, M. Muhler, R.A. Fischer, Y. Wang, U. Schatzschneider, N. Metzler-Nolte, Chem. Eur. J. 2013, 19, 6785-6790.

[29] F.J. Carmona, S. Rojas, P. Sánchez, H. Jeremias, A.R. Marques, C.C. Romão, D. Choquesillo-Lazarte, J.A.R. Navarro, C.R. Maldonado, E. Barea, Inorg. Chem. 2016, 55, 6525-6531.

[30] S. Diring, A. Carné-Sánchez, J. Zhang, S. Ikemura, C. Kim, H. Inaba, S. Kitagawa, S. Furukawa, Chem. Sci. 2017, 8, 2381-2386.

[31] F. J. Carmona, S. Rojas, C. C. Romão, J.A.R. Navarro, E. Barea, C.R. Maldonado, Chem. Commun. 2017, 53, 6581-6584.

[32] F. J. Carmona, C. R. Maldonado, S. Ikemura, C. C. Romão, Z. Huang H. Xu, X. Zou, S. Kitagawa, S. Furukawa, E. Barea, ACS Appl. Mater. Interfaces 2018, 10, 31158-31167.

[33] Z. Jin, P. Zhao, J. Zhang, T. Yang, G. Zhou, D. Zhang, T. Wang, Q. He, Chem. Eur. J. 2018, 24, 11667-11674

[34] K. Ladewig, Z.P. Xu, G.Q. (Max) Lu, Expert Opin. Drug Deliv. 2009, 6, 907-922.

[35] R. Liang, M. Wei, D.G. Evans, X. Duan, Chem. Commun. 2014, 50, 14071-14081.

[36] V. Rives, M. del Arco, C. Martín, Appl. Clay Sci. 2014, 88-89, 239-269.

[37] L. Yan, S. Gonca, G. Zhu, W. Zhang, X. Chen, J. Mater. Chem. B 2019, 7, 5583-5601

[38] D.G. Evans, R.C.T. Slade, Structural aspects of layered double hydroxides, in Layered Double Hydroxides (Eds. X. Duan, D.G. Evans), Structure and Bonding, vol. 119, Springer, Berlin, Heidelberg, 2006, pp. 1-87.

[39] G. Arrabito, A. Bonasera, G. Prestopino, A. Orsini, A. Mattoccia, E. Martinelli, B. Pignataro, P.G. Medaglia, Crystals 2019, 9, article no. 361; doi:10.3390/cryst9070361.

[40] J.-M. Oh, S.-J. Choi, S.-T. Kim, J.-H. Choy, Bioconjugate Chem. 2006, 17, 1411-1417.
[41] Z.P. Xu, M. Niebert, K. Porazik, T.L. Walker, H.M. Cooper, A.P.J. Middelberg, P.P. Gray, P.F. Bartlett, G.Q. (Max) Lu, J. Controlled Release 2008, 130, 86-94.

[42] A.C. Gomes, S.M. Bruno, C.A. Gamelas, A.A. Valente, M. Abrantes, I.S Gonçalves, C.C. Romão, M. Pillinger, Dalton Trans. 2013, 42, 82318240.

[43] A.C. Gomes, S.M. Bruno, A.A. Valente, I.S. Gonçalves, M. Pillinger, J. Organomet. Chem. 2013, 744, 53-59.

[44] A.C. Gomes, S.M. Bruno, M. Abrantes, C.I.R. Magalhães, I.S. Gonçalves, A.A. Valente, M. Pillinger, J. Organomet. Chem. 2014, 760 , 205-211.

[45] A.R. Marques, L. Kromer, D.J. Gallo, N. Penacho, S.S. Rodrigues, J.D. Seixas, G.J.L. Bernardes, P.M. Reis, S.L. Otterbein, R.A. Ruggieri, A.S.G. Gonçalves, A.M.L. Gonçalves, M.N. De Matos, I. Bento, L.E. Otterbein, W.A. Blättler, C.C. Romão, Organometallics 2012, 31, 58105822.

[46] L. S. Nogueira, P. Neves, A. C. Gomes, T. A. Amarante, F. A. A. Paz, A. A. Valente, I. S. Gonçalves, M. Pillinger, Molecules 2019, 24, article no. 105; doi:10.3390/molecules24010105.

[47] M. Badreddine, A. Legrouri, A. Barroug, A. De Roy, J. P. Besse, Mater. Lett. 1999, 38, 391-395.

[48] A. J. Atkin, J. M. Lynam, B. E. Moulton, P. Sawle, R. Motterlini, N. M. Boyle, M. T. Pryce, I. J. S. Fairlamb, Dalton Trans. 2011, 40, 57555761

[49] S. McLean, B. E. Mann, R. K. Poole, Anal. Biochem. 2012, 427, 36-40.

[50] T. Zhang, M. Li, Y. Gong, N. Xi, Y. Zheng, Q. Zhao, Y. Chen, B. Liu, J Biol. Inorg. Chem. 2016, 21, 807-824.

[51] Y. Li, Y. Shu, M. Liang, X. Xie, X. Jiao, X. Wang, B. Tang, Angew. Chem. Int. Ed. 2018, 57, 12415-12419.

[52] Z. Jin, Y. Wen, L. Xiong, T. Yang, P. Zhao, L. Tan, T. Wang, Z. Qian, B.-L. Su, Q. He, Chem. Commun. 2017, 53, 5557-5560.

[53] A. L. Costa, A. C. Gomes, M. Pillinger, I. S. Gonçalves, J. Pina, J. S. Seixas de Melo, ChemPhysChem 2017, 18, 564-575.

[54] E. W. Abel, M. A. Bennett, R. Burton, G. Wilkinson, J. Chem. Soc. 1958, 4559-4563. 


\section{Entry for the Table of Contents}

\section{FULL PAPER}

A photoactive carbon monoxide releasing material with a high $\mathrm{CO}$ payload has been prepared by using a layered double hydroxide as a carrier system for a molybdenum carbonyl isocyanoacetate prodrug. Myoglobin and gas chromatography assays were used to track light-induced and $\mathrm{H}_{2} \mathrm{O}_{2-}$ triggered loss of $\mathrm{CO}$. Leaching tests in biological buffer solution show the high capacity of the inorganic host to retain the unaltered complex and decarbonylation fragments.

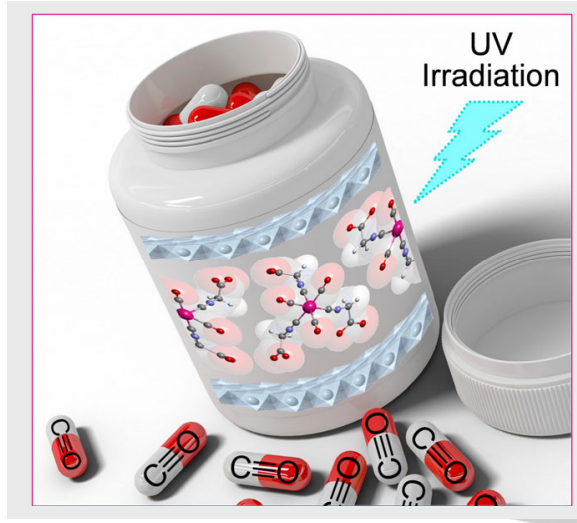

\section{CO-Releasing Materials}

Isabel M. Calhau, Ana C. Gomes, Sofia M. Bruno, Ana C. Coelho, Clara I. R. Magalhães, Carlos C. Romão, Anabela A. Valente, Isabel S. Gonçalves, and Martyn Pillinger

Page No. - Page No.

One-pot intercalation strategy for the encapsulation of a CO-releasing organometallic molecule in a layered double hydroxide 